\title{
O Professor, a Escola e a Avaliação
}

\author{
Menga Lũdke*
}

Embora seja um assunto abordado freqüentemente nos meios educacionais, a avaliação é quase invariavelmente tratada como utn assunto referente especificamente aos alunos. Por que se cobra só do aluno uma tarefa que é muito mais da tesponsabilidade da escola, com toda a sua equipe técnica e docente, destacando-se especialmente a parte que cabe ao professor? Gostaria justamente de deslocar esse eixo da vida escolar, centrando estas consideraçōes sobre a avaliação no pólo correspondente à escola e ao professor, ao invés de focalizar o alvo comumente apontado como responsável pelo fracasso escolat, o aluno. Se ele fracassa, certamente é porque alguma coisa não anda bem nos outros setores do complexo processo educacional, pois ele, o aluno, é o sujeito/objeto principal desse processo, sofrendo e refletindo em sua própria trajetória escolar seus acertos e erros, com consequuêneias muitas vezes para toda a sua vida.

Já se disse que a avaliação é um dos espelhos mais fiẻis da sociedade à qual o sistema educacional está servindo. Através da avaliação se fiscaliza, o mais exatamente possivel, se a escola está passando eficientemente, para as novas geraçöes, os valores e prioridades que regern a vida dessa sociedade. As atividades e disciplinas selecionadas para entrarem na composição curricular, inclusive os tópicos escolhidos dentro de cada disciplina, correspondem sem dúvida a uma ordem de prioridades vigente na sociedade mais ampla, onde a escola se insere.

Observa-se a esse respeito a competị̧ão entre os vários campos estabelecidos do saber, toda vez que se trata de alterar a composição curricular, conno agora mesmo está se fazendo a partir da nova Lei de Diretrizes e Bases da Educação Nacional.

Além da importante função de auxiliar na preservação dos saberes que a sociedade julga importante garantir, através da educação, a avaliação desempenha uma outra função, mais sutil, certamente, mas não menos contundente: a de selecionar, justamente a partir do domínio desses saberes, os alunos que no futuro irão assumir os papéis de comando, de liderança no mundo econômico e aqueles que, exatamente por não demostrarem esse domítilo, serão destinados às funçães menos relevantes, mais rotineiras, mas também básicas para a sustentação da estrutura sócio-econôtnica dominante. Năo se trata apenas de garattir pela educação (e verificar pela avaliação) que determinados alunos detêtn as informações substantivas corretas, telativas aos conteúdos considerados importantes. Trata-se também de

* Professora da Universidade Federal Fuminense (JPF) e da Pontficia Universidade Catolica do Rio de Jantiro (PUC-RJ). 
assegurar, pelo trabalho da escola, a passagem efetiva de atitudes e comportamentos próprios aos futuros ocupantes de posições diferentes na sociedade: para alguns a atitude critica, questionadora e segura dos lideres, para outros a disciplina e subordinação dos liderados.

Não faz muito tempo, entretanto, que a avaliação e a própria educação vêm sendo estudadas e entendidas como ligadas a essas funçôes. No que se tefere à avaliação, especialmente, até há bem pouco tempo, se costumava estudá-la como simples instrumental de verificação da aprendizagem, enfatizando-se seus aspectos técnicos. Hoje, felizmente, as discussões sobre o assunto já incluem a avaliação em um contexto bem mais amplo, que abrange suas importantes conseqüências sociais, sem desconhecer, é claro, seus aspectos técnicos.

Que acontece, porém, na escola, e na sala de aula, onde se desenrolam as cenas principais do ato educativo? É muito importante que o professor e toda a equipe técnica e administrativa da escola estejam conscientes das implicações sociais do processo de avaliação. Não basta saber que ele se atrela ao fenômeno mais amplo da educação e conhecer as principais discussões teóricas atualmente desenvolvidas a respeito desta. É preciso procurar destrinchar como, na prática, funcionam os delicados mecanismos do controle exercido pela avaliação em favor de uma determinada ordem social. É preciso sobretudo saber se é essa a ordem que gostariamos de preservar, ou se temos em mente um outro tipo de organização social, que deveria ser servida por um outro tipo de distribuição do saber. Em suma, se gostaríamos de contribuir com a educação e a avaliação para a manutenção da sociedade tal qual se encontra, ou se gostariamos que elas se voltassem para a sua transformação em uma sociedade mais justa e igualitária.

Muito do que se passa dentro dos muros de uma escola não é transparente nem mestno para os seus participantes mais diretos. Quantas vezes ao dar uma nota, ao elaborar uma prova ou tomar parte em um Conselho de Classe, um professor, ainda que bastante atento à realidade sócio-política, não se deixa levar por uma trama invisivel, tomando uma decisão que acaba punindo individualmente o aluno, por ser membro de uma coletividade, ou seja, porque ele não está equipado com qualidades e recursos que sua familia e seu meio social de origem não puderam the garantir.

Considerando a escola de $2^{g}$ grau, especificamente a da rede pública, percebe-se clatamente o efeito contínuo exercido por aqueles mecanismos de controle mencionados, que vão selecionando eficientetnente, ano após ano, desde (e principalmente) os primeiros anos do $1^{\circ} \mathrm{grau}$, permitindo que chegue ao $2^{2}$ grau apenas um pequeno contingente de alunos. O que acontece então com esses alunos? Tive ocasião de participar, como orientadora, de uma dissertação de mestrado, na UFF, sobre a avaliação na escola de $2^{\circ}$ grau, na qual a autora, Sonia Duprat, constata em estudo efetuado em uma grande escola pública do grande Rio, a presença evidente e os efeitos desses mecanismos sobre os alunos.

Surpreendentemente, apesar de serem alunos selecionados de longa data, ainda há um grande número de reprovações, sobretudo no $1^{\mathfrak{Q}}$ ano. Um pequeno número consegue atravessar as barreiras e se candidatar ao vestibular. Se serão aprovados é outra história. E os outros, que ficam pelo caminho, que faz a escola por eles?

(1) - DUPRAT, S. (1989) - A prática da avaliaçäo na escola de $2^{\ell}$ grau. Dissertaçăo de Mestrado. Faculdade de Educaçắo, U.F.F. Rio de Janeiro. 
Gostaria de concluir com algumas indagações dirigidas aos professores do $2^{\circ}$ grau e a todos nós. Ả luz da reflexão sobre os intrincados mecanistnos da avaliação, mas também atentando para as múltiplas direções que o trabalho da escola pode (e deve) assumir, pergunto: para que serve a escola de $2^{2}$ grau, a quem ela serve? De quetn é essa escola? Dos seus diretores e professores, como às vezes parece, ou de seus alunos, de todos os seus alunos? 
